\title{
Impact of Dramatization and Lecture Methods on Effective Teaching of Yoruba Poetry in Secondary Schools in Lagos State, Nigeria
}

\author{
Abatan, O. Luke \\ Tai Solarin University of Education, Department of Languages, \\ College of Humanities, ljebu-Ode, Ogun State \\ Lukeabatan@yahoo.com
}

\section{Doi:10.5901/jesr.2014.v4n3p161}

\begin{abstract}
This study examines the impact of dramatization and lecture methods on effective teaching of Yoruba Poetry in Secondary Schools in Lagos State. It finds out the effect of using dramatization and lecture methods in widening students understanding of poetry in Yoruba Language. The researcher adopted the descriptive survey research design. the study sampled 10 public secondary schools and 200 students offering the subject using simple random sapling technique. A self-designed achievement test tagged: "Yoruba Poetry Achievement Test (YPAT)" with a reliability coefficient (r) of 0.62 was used to assess the performance of students in order to establish effective teaching of Yoruba poetry. Pearson product moment correlation coefficient (r) and t-test were used to analyse the data. While the null hypotheses developed for the study were tested at .05 level of significance. The findings revealed significant relationship between dramatization method, lecture method, and students' performance in Yoruba poetry. Also, there is significant difference in the performance of students taught Yoruba poetry using lecture method and dramatization method. The study recommended among others that teachers in various secondary schools should equip themselves with knowledge in use of different methods of teaching so as to enable them diversify their method of teaching as soon as they observe that the method in use does not benefit the student in the teaching process.
\end{abstract}

Keywords: Teaching methods, Education, Curriculum, Communication, Lesson delivery, Teachers

\section{Introduction}

Teaching methods are the methods or the ways through which a teacher want to realize his teaching goals or objectives and a source through which a teacher implements his or her lesson note (Amo0, 2009). There are so many methods of teaching open to a teacher in a teaching-learning exercise. Every classroom teacher consequently makes use of one or two of these methods. Though, the method to be used depends on some factors, yet a teacher has the freedom to choose the one that will make him achieve his aims. Virtually all methods of teaching have their own merits and demerit and also different situations of usage but all have common goals, which are aims and objectives of teaching method.

Adewoyin (2001) opines that the best curriculum and the most perfect syllabus remain dead unless quickened into life by the right method of teaching. The right method of teaching is also seen as the most important, yardstick for the determination of the quality of the result. Despite the usefulness and importance of teaching methods, many people still have different opinions on the effects of various teaching methods adopted by the teacher in the course of teaching and looking at the performance in various subjects.

For instance, many scholars believe that failure in selecting an appropriate method of teaching for a particular topic will definitely lead to failure in achieving the aims, objective of the lesson (Akinlaye, Mansary and Ajiboye, 1996). In addition many teachers have chosen a teaching method based on their experience and convenience without considering the learners' characteristics and the nature of the topic to be taught. This wrong choice of teaching methods has greatly affected learners grasping the content of the subject considering the way teachers select methods of teaching in our schools. One can conclude that the teachers' effort in teaching is useless and ineffective if he fails to effectively choose an appropriate method.

The lecture method of teaching is an economic means of transmitting factual information to a larger audience even though there is no guarantee that effective learning will result. This method is characterized by one-way communication from the teacher to the class. It also autocratically informs and allows little or no room for active student participation. This method, through wide used in Nigeria Secondary School system, does not result in noticeable change in attitude held, while retention of information disseminated is also very poor. 
Awoniyi (1997) views the concept of dramatization of real life situation by student. It is also natural method of learning. The method can be said to accomplish over objectives like self development, skill acquisition and to facilitate the understanding of other behaviour and emotion of other people. There is no doubt the type of effects it will have on teaching and learning of such subject like poetry in Yoruba.

Dramatization involves the use of acting to teach or learn. This can be inform or dramatization as a tools of achieving the objectives of teaching and learning Yoruba poetry, would equip the learner's with the right forms of values, skills to improve the standard and enhance other quality of life.

\section{Statement of the Problem}

This study examined the relationship between both dramatization and lecture methods and secondary school students' performance in Yoruba Poetry in Lagos State. Since the students' academic performance indicates how effective the methods used in the teaching are. It is the intension of the researcher to use the study findings in making useful recommendations on the effective teaching of Yoruba Poetry in secondary schools.

\section{Research Questions}

The following research questions were raised to guide the study.

1. In what way is lecture method and dramatization method important in teaching Yoruba poetry?

2. Does the use of and dramatization methods have positive impact on the performance of students in Yoruba poetry?

\section{Research Hypotheses}

- Ho1: There is no significant relationship between use of dramatization method and students' performance in Yoruba poetry.

- Ho2: There is no significant relationship between use of lecture method and students' performance in Yoruba poetry.

- $\mathrm{H}_{3}$ : There is no significant difference in the performance of students taught Yoruba poetry using lecture method and dramatization method.

\section{Methodology}

This research sample covered ten secondary schools in Lagos State. The ten secondary schools were randomly selected across the local government to serve as sample for the study using simple random sampling technique. The two methods (lecture and dramatization) were used to teach Yoruba poetry in five secondary schools respectively for the sake of comparison. While a self-designed achievement test tagged: "Yoruba Poetry Achievement Test (YPAT)" with a reliability coefficient ( $r$ ) of 0.62 was developed to assess the performance of 200 Yoruba students in order to establish effective teaching of Yoruba poetry. The achievement test comprises two sections. Section A sought demographic information such as a name of the student, school, sex and age of the student while section B was based on the questions to get students response on the research topic. The data collected were analysed with the use of Pearson product moment correlation co-efficient $(r)$ and t-test statistics, the null hypotheses developed for the study were tested through 0.05 level of significance.

\section{Presentation of Results and Discussion}

The results of the study are presented according to the null hypotheses developed for the study.

$\mathrm{H}_{1}$ : There is no significant relationship between use of dramatization method and students' performance in Yoruba poetry. 
Table 1: Relationship between Use of Dramatization Method and Students' Performance in Yoruba Poetry

$P<0.05$

\begin{tabular}{|l|c|c|c|c|c|}
\hline Variable & $\mathbf{N}$ & $\mathbf{d f}$ & Observed(r) & Tabulated(r) & Remark \\
\hline Use of Dramatization Method & 200 & & & & \\
\hline & & 198 & 0.563 & .159 & Sig. \\
\hline Students' Performance & 200 & & & & \\
\hline
\end{tabular}

From Table 1 above, the observed $r=.563$ and the tabulated $r=.159$ at 0.05 level of significance. The observed $r$ - value is greater than the tabulated $r$-value. Therefore, the null hypothesis, which states that, there is no significant relationship between use of dramatization method and students' performance in Yoruba poetry, is rejected. This indicates that there is significant relationship between use of dramatization method and students' performance in Yoruba poetry.

This implies that dramatization method enhances the performance of students of Yoruba poetry in Secondary School. This result buttresses Rybuam (2005), who observed that dramatization method enhances the retention of knowledge acquired. It will equally broaden the students' understanding, which in turn reflects positively in their academic performance.

$\mathrm{Ho}_{2}$ : There is no significant relationship between use of lecture method and students' performance in Yoruba poetry.

Table 2: Relationship between Use of Lecture Method and Students' Performance in Yoruba Poetry

\begin{tabular}{|l|c|c|c|c|c|}
\hline Variable & $\mathbf{N}$ & df & Observed(r) & Tabulated(r) & Remark \\
\hline Use of Lecture Method & 200 & & & & \\
\hline & & 198 & 0.671 & .159 & Sig. \\
\hline Students' Performance & 200 & & & & \\
\hline
\end{tabular}

$\mathrm{P}<0.05$

From Table 2 above, the observed $r=.671$ and the tabulated $r=.159$ at 0.05 level of significance. The observed $r$ - value is greater than the tabulated $r$-value. Therefore, the null hypothesis, which states that, there is no significant relationship between use of lecture method and students' performance in Yoruba poetry, is rejected. This indicates that there is significant relationship between use of lecture method and students' performance in Yoruba poetry.

This result is in agreement with Adewoyin (2001), who found that lecture method is significantly related to student achievement because it allows the teacher to cover a large number of topics of the syllabus. While the result of the present study disagrees with Clerk (2002) and Rivlin, (2001), who believed that that lecture method is not effective at lower level of education but only adequate at higher level of education due to the background of the students at such level.

Ho3: There is no significant difference in the performance of students taught Yoruba poetry using lecture method and dramatization method.

Table 3: Difference in the Performance of Students Taught Yoruba Poetry Using Lecture and Methods

\begin{tabular}{|l|c|c|c|c|c|c|c|c|c|c|}
\hline Variables & Number & Mean & Std Dev. & Df & t.obs & t.tab & P & Remark \\
\hline Performance of Students Taught with Dramatization Method & 200 & 35.8 & 4.9 & 198 & 2.12 & 1.96 & 0.05 & S \\
\hline Performance of Students Taught with Lecture Method & 200 & 53.2 & 6.8 & & & & & \\
\hline
\end{tabular}

Table 3 above shows that the observed $t=2.12$ and the tabulated $t=.1 .96$ at 0.05 level of significance. The observed $t$ value is greater than the tabulated $t$ - value. Therefore, the null hypothesis, which states that, there is no significant difference in the performance of students taught Yoruba poetry using lecture method and dramatization method, is rejected. This indicates that there is significant difference in the performance of students taught Yoruba poetry using lecture method and dramatization method.

This result is unconnected with the fact that the methods used in teaching the students are different. This also indicates that one method is more effective than the other as reflected in the students' performances. This result is in agreement with Akinlaye, Mansary, and Ajiboye (1996), who found that the method of teaching has significant 
relationship on students' the students' performance in social studies.

\section{Conclusion}

This study examined the impact of both dramatization and lecture methods and secondary school students' performance in Yoruba Poetry in Lagos State. The study found that there is significant relationship between dramatization method, lecture method and students' performance in Yoruba poetry. Also, there is significant difference in the performance of students taught Yoruba poetry using lecture method and dramatization method.

It should be stated that the use of dramatization method recorded highest number of successful students in Yoruba poetry, which makes it the best method of teaching Yoruba poetry. Really, in the passive recipient view, it makes some sense to think of successful teaching arising solely from the actions of a teacher. That is, learning on the part of the student is indeed a direct result of actions by a teacher. Yet we all know that learners are not passive receptors of information directed at them. Learning does not arise solely on the basis of teacher activity. Therefore, students involvement in the teaching-process is highly necessary. This is exactly what dramatization method does in the teaching process.

\section{Recommendations}

Based on the above findings, the following recommendations were proffered on the effective teaching of Yoruba Poetry in secondary schools.

Their schools with materials for principal project method of teaching.

- Teachers in various secondary schools should equip themselves with knowledge in use of different methods of teaching so as to enable them diversify their method of teaching as soon as they observe that the method in use does not benefit the student in the teaching process.

- Teachers should not stick to only a particular method in delivering their lesson, they should be able to text different methods and adopt the best appropriate one for the subject they teach.

- It should be noted that dramatization method is highly suitable for the teaching of Yoruba poetry.

- Efforts should be made by teachers to employ the two methods to complement each other in order to help the students gain maximally in the class and record high academic performance.

- In addition, there should be a conducive classroom environment for the use of dramatization method and for easing assimilation of students.

- Finally, there should be adequate provision of institutional materials suitable for difference methods teaching in the class.

\section{References}

Adewoyin, T.A. (2001). Introduction to Educational Technology. Lagos: John-led Published Limited.

Akinlaye, F.A Mansary, A. and Ajiboye, J. O. (1996). Fundamental of Teaching Social Studies, Ibadan: Puman Nigeria Ltd. Educational Publishers.

Amoo, T.L. (2009). Fundamental of Teaching in Secondary Schools. New York: Odyssey Press.

Awoniyi, T. (1997). Principles and Practices of Education. London: Utidher and Songhton.

Clerk (2002). Teaching Social Studies Secondary School. New York: Macmillan Publishing.

Rivlin, H.N. (2001). Teaching Adolescent in Secondary Schools. New York: Appleton Century Crofts.

Rybuam, W. M. (2005). The Principles of Teaching. London: Oxford University Press. 